\title{
PENGARUH STRUKTUR MODAL, AGENCY COST, DAN DIVIDEND PAYOUT RATIO TERHADAP KINERJA PERUSAHAAN YANG TERDAFTAR DI BURSA EFEK INDONESIA TAHUN 2008-2012
}

Eka Nuraini Rachmawati

Ayu

\begin{abstract}
Abstrak
Penelitian ini bertujuan untuk menguji pengaruh secara silmutan dan parsial variabel struktur modal, agency cost dan dividend payout ratio terhadap kinerja perusahaan yang terdaftar di Bursa Efek Indonesia. Penentuan sampel berdasarkan metode purposive sampling, sampel diambil sebanyak 10 perusahaan pada tahun 2008-2012. Analisis data menggunakan analisis regresi berganda. Hasil penelitian menunjukkan bahwa struktur modal berpengaruh positif dan signifikan terhadap kinerja perusahaan dan agency cost berpengaruh negatif dan signifikan terhadap kinerja perusahaan. Namun dividend payout ratio tidak mempunyai pengaruh terhadap kinerja perusahaan. Secara simultan struktur modal, agency cost dan dividend payout ratio mempunyai pengaruh signifikan terhadap Kinerja Perusahaan yang terdaftar di Bursa Efek Indonesia.
\end{abstract}

(Universitas Islam Riau - Pekanbaru)

Kata kunci : Struktur modal, Agency Cost, DPR dan Kinerja Perusahaan

\section{PENDAHULUAN}

Kinerja perusahaan akan terlihat dari perolehan laba, peningkatan laba secara tidak langsung akan memberikan kesejahteraan bagi para pemegang saham berupa deviden atau capital gain. Tingkat keuntungan yang akan diterima oleh pemegang saham ditentukan oleh deviden yang dilihat dari harga saham, apabila harga saham tinggi maka keuntungan yang akan diterima sharehorder juga tinggi karena harga saham bisa dijadikan tolak ukur dalam menjaga kemakmuran para pemegang saham. Didalam perusahaan juga terdapat beberapa fungsi, diantaranya fungsi pengelolaan dan fungsi kepemilikan. Jensen dan Meckling (1976) mengatakan bahwa pemisahan fungsi pengelolaan sangat rentan dengan agency conflict (Fachrudin, 2011).
Struktur modal menunjukkan proporsi atas penggunaan hutang untuk membiayai investasinya, sehingga dengan mengetahui struktur modal, investor dapat mengetahui keseimbangan antara resiko dan tingkat pengembalian investasinya. Dalam penelitian Khaira Amalia Fachrudin menujukkan bahwa struktur modal berpengaruh terhadap kinerja perusahaan karena hutang mampu meningkatkan produktifitas sehingga penjualan meningkat. Menurut Myers (1996) perusahaan lebih menyukai penggunaan pendanaan dari modal internal, yaitu dana yang berasal dari aliran kas, laba ditahan dan depresiasi. Hal ini untuk menghindari sorotan serta ikut campur pihak luar dalam pengelolaan perusahaan. Struktur modal merupakan masalah penting karena baik buruknya struktur modal akan berdampak langsung terhadap keuangan perusahaan. 
Sehingga menuntut para manajer agar mampu pengolahan dana dengan sebaik-baiknya, selain itu struktur modal harus lebih kecil dari modal sendiri karena apabila struktur modal lebih besar dari modal sendiri, hal ini tidak sesuai dengan teori struktur modal yang optimal dimana jumlah hutang perusahaan harus lebih kecil dari modal sendiri.

ROE dapat menjadi ukuran efisiensi penggunaan modal sendiri yang dioperasionalkan dalam perusahaan. Namun penggunaan dana eksternal mampu meminimalkan pajak, karena beban bunga dapat dikurangkan dari pendapatan sehingga laba sebelum pajak menjadi lebih kecil dan pajak semakin kecil pula. Inilah salah satu stategi perusahaan dalam menjalankan kegiatan operasionalnya selain mendapatkan tambahan dana dari pihak luar, namun juga mampu memininalkan pajak yang harus ditanggung oleh perusahaan.

Kebijakan deviden sangat rentan dengan konflik yang terjadi antara manajemen dan pemegang saham atau sering dikenal dengan agency conflict (konflik kepentingan). Agency conflict sering terjadi kala manajer cenderung membuat keputusan yang menguntungkan dirinya daripada kepentingan pemegang saham (Meckling 1976, Myers 1977). Tidak hanya itu agency conflict bisa terjadi antara pemegang saham pengendali dan pemegang saham minoritas, antara pemegang saham pengendali dan stakeholder lainnya, termasuk pemasok dan karyawan (Asian development bank dalam husnan, 2001). Hal ini yang mendorong timbulnya agency cost (biaya agensi). Weston J. Fred dan E.F. Brgiham( 1990:21), meyebutkan bahwa agency cost adalah biaya yang berhubungan dengan monitoring tindakan manajer untuk menyatakan bahwa tindakan manajer konsisten dengan persetujuan kontrak antara manajer, pemegang saham dan kreditur. Para pemegang saham dan kreditor mengeluarkan agency cost atau biaya keagenan untuk mengawasi manajer dalam melaksanakan kebijakan deviden di dalam perusahaan karena para pemegang saham menginginkan keuntungan atau laba yang pasti dan selalu dibagikan.

Dalam literatur finance, Jensen dan Meckling (1976), hal yang pertama menghubungkan agency cost dengan hutang dalam struktur modal. Penggunaan hutang dalam struktur modal dapat mencegah pengeluaran perusahaan yang tidak penting dan memberikan dorongan pada manajer untuk mengoperasikan perusahaan dengan lebih efisien. Hal tersebut menyebabkan agency cost berkurang dan selanjutnya kinerja perusahaan diharapkan akan meningkat (Cao,2006).

Agency cost mempunyai hubungan dengan kebijakan dividen suatu perusahaan. Apabila tingkat agency cost tinggi maka hal ini berdampak buruk bagi pemegang saham. Pemegang saham akan mendapatkan dividen yang rendah, hal ini dikarenakan manajer akan menggunakan dana-dana secara berlebih dan akan berdampak pada penurunan profitabilitas perusahaan dan berdampak pada kinerja perusahaan yang buruk, karena para manajer berlaku tidak konsisten dalam mencapai tujuan perusahaan. Perkembangan bisnis di perusahaan seluruh sektor yang terdaftar di Bursa Efek Indonesia harus diimbangi dengan kinerja perusahaan yang baik. Kinerja perusahaan akan memperlihatkan kemampuan perusahaan untuk memberikan keuntungan dari aset, ekuitas, maupun hutang. Salah satu ukuran kinerja perusahaan adalah Return on Equity (ROE). ROE adalah ukuran profitabilitas perusahaan penting yang mengukur pengembalian untuk pemegang saham (Jones et al. 2009). ROE dapat dijadikan ukuran efesiensi penggunaan modal 
sendiri yang dioperasionalkan dalam perusahaan. Semakin besar ROE, semakin besar kemampuan perusahaan menghasilkan laba bagi pemegang saham (Fachrudin, 2011).

Berdasarkan uraian diatas maka penelitian ini mengambil judul " Pengaruh struktur modal, agency cost dan dividend payout ratio terhadap kinerja perusahaan yang terdaftar di Bursa Efek Indonesia Tahun 20082012".

\section{Perumusan Masalah}

Berdasarkan uraian sebelumnya maka rumusan masalah pada penelitian ini adalah: "Apakah struktur modal, agency cost dan dividend payout ratio berpengaruh secara silmutan dan parsial terhadap kinerja perusahaan yang terdaftar di Bursa Efek Indonesia Tahun 2008-2012."

\section{Tujuan Penelitian}

Berdasarkan rumusan masalah yang dikemukakan di atas maka tujuan peneliti adalah :

Untuk menguji pengaruh struktur modal, agency cost, dan dividend payout rasio terhadap kinerja perusahaan yang terdaftar di Bursa Efek Indonesia Tahun 2008 - 2012”.

\section{Telaah Pustaka}

\section{Kinerja Perusahaan}

Kinerja perusahaan merupakan suatu gambaran tentang kondisi keuangan suatu perusahaan yang dianalisis dengan alat-alat analisis keuangan, sehingga dapat diketahui mengenai baik buruknya keadaan keuangan suatu perusahaan yang mencerminkan prestasi kerja dalam periode tertentu. Hal ini sangat penting agar sumber daya digunakan secara optimal dalam menghadapi perubahan lingkungan.

Penilaian kinerja keuangan merupakan salah satu cara yang dapat dilakukan oleh pihak manajemen agar dapat memenuhi kewajibannya terhadap para penyandang dana dan juga untuk mencapai tujuan yang telah ditetapkan oleh perusahaan. Beberapa pengertian kinerja seperti yang telah dijelaskan oleh Helfert (1996:67) bahwa "Kinerja perusahaan adalah hasil dari banyak keputusan individual yang dibuat secara terus menerus oleh manajemen."

Dari pendapat tersebut dapat diketahui bahwa kinerja merupakan indikator dari baik buruknya keputusan manajemen dalam pengambilan keputusan. Manajemen dapat berinteraksi dengan lingkungan internal maupun eksternal melalui informasi. Informasi tersebut lebih lanjut dituangkan atau dirangkum dalam laporan keuangan perusahaan. Pengertian lain tentang kinerja yaitu "Performance adalah ukuran seberapa efisien dan efektif sebuah organisasi atau seorang manajer untuk mencapai tujuan yang memadai." (Stoner et al, 1996:9)

\section{Struktur Modal}

Menurut Riyanto (1997) struktur modal adalah pembelanjaan permanen yang mencerminkan pertimbangan atau perbandingan antara utang jangka panjang dengan modal sendiri. Struktur modal menunjukan proporsi atas penggunaan utang untuk membiayai investasinya, sehingga dengan mengetahui struktur modal investor dapat mengetahui keseimbangan antara risiko dan tingkat pengembalian investasinya. Menurut Riyanto (2001 : 296) Struktur Modal adalah perimbangan atau perbandingan antara modal asing (jangka panjang) dengan modal sendiri. Modal asing dalam bentuk hutang baik jangka panjang maupun jangka pendek dari pihak luar, sedangkan modal sendiri bisa berasal dari laba ataupun kesertaan modal pemilik. Struktur modal merupakan proporsi atau perbandingan dalam menentukan pemenuhan kebutuhan belanja perusahaan, apakah dengan cara menggunakan utang, ekuitas, atau dengan menerbitkan saham 
(Birgham dan Gapensi : 1996) dalam penelitian Tinjung Desy Nursanti (2004).

\subsection{Teori Struktur Modal}

Menurut Atmaja (2008) ada enam teori tentang struktur modal sebagai berikut :

a. Model Modigliani-Miller (MM) dengan Pajak

Pada tahun 1958, dua ahli manajemen keuangan Franco Modigliani dan Merton Miller mengajukan suatu teori yang ilmiah tentang struktur modal perusahaanModel Modigliani-Miller Dengan Pajak. Tahun 1963, MM menerbitkan artikel sebagai lanjutan teori MM tahun 1958. Asumsi yang diubah adalah adanya pajak terhadap penghasilan perusahaan (corporate income taxes). Dengan adanya pajak, MM menyimpulkan bahwa penggunaan hutang (leverage) akan meningkatkan nilai perusahaan karena biaya hutang adalah biaya yang mengurangi pembayaran pajak ( $a$ tax deductible expense).

\section{b. Financial Distress dan Agency Cost \\ Financial distress adalah kondisi dimana} perusahaan mengalami kebangkrutan, maka akan timbul biaya kebangkrutan. Selain itu acaman terjadinya financial distress juga merupakan biaya karena manajemen cenderung menghabiskan waktu untuk menghindari kebangrutan dari pada membuat keputusan perusahaan yang baik. Pada umumnya, terjadinya financial distress semakin meningkat dengan meningkatnya penggunaan hutang. Agency cost adalah biaya yang timbul karena perusahaan menggunakan hutang dan melibatkan hubungan antara pemilik perusahaan dan kreditor. Biaya keagenan ini muncul karena adanya agency problem. Agency cost terdiri dari biaya kehilangan kebebasan atau efisiensi dan biaya untuk memonitor perusahaan.

c. Model Trade-Off
Menurut trade-off theory yang diungkapkan oleh Myers (2001:81), "Perusahaan akan berhutang sampai pada tingkat utang tertentu, dimana penghematan pajak (tax shields) dari tambahan hutang sama dengan biaya kesulitan keuangan (financial distress)". Biaya kesulitan keuangan (financial distress) adalah biaya kebangkrutan (bankruptcy cost) atau reorganization, dan biaya keagenan (agency cost) yang meningkat akibat dari turunnya kredibilitas suatu perusahaan. Trade-off theory dalam menentukan struktur modal yang optimal memasukkan beberapa faktor antara lain pajak, biaya keagenan (agency costs) dan biaya kesulitan keuangan (financial distress) tetapi tetap mempertahankan asumsi efisiensi pasar dan symmetric information sebagai imbangan dan manfaat penggunaan utang. Tingkat utang yang optimal tercapai ketika penghematan pajak (tax shields) mencapai jumlah yang maksimal terhadap biaya kesulitan keuangan (costs of financial distress). Trade-off theory mempunyai implikasi bahwa manajer akan berpikir dalam kerangka trade-off antara penghematan pajak dan biaya kesulitan keuangan dalam penentuan struktur modal. Perusahaanperusahaan dengan tingkat profitabilitas yang tinggi tentu akan berusaha mengurangi pajaknya dengan cara meningkatkan rasio utangnya, sehingga tambahan utang tersebut akan mengurangi pajak.

d. Pecking Order Theory

Menurut Myers (2001), pecking order theory menyatakan bahwa "Perusahaan dengan tingkat profitabilitas yang tinggi justru tingkat utangnya rendah, dikarenakan perusahaan yang profitabilitasnya tinggi memiliki sumber dana internal yang berlimpah." Dalam pecking order theory ini tidak terdapat struktur modal yang optimal. Secara spesifik perusahaan mempunyai urut- 
urutan preferensi (hierarki) dalam penggunaan dana.

\section{e. Equity Market Timing}

Teori yang diungkapkan oleh Baker dan Wurgler (2002:1) ini mengemukakan bahwa "Perusahaan-perusahaan akan menerbitkan ekuitas pada saat nilai pasar tinggi dan akan membeli kembali ekuitas pada saat nilai pasar rendah". Praktik inilah yang kemudian disebut sebagai equity market timing.

f. Teori Informasi yang Tidak Simetris (Asymmetric Information Theory)

Awal dekade 1960-an, Gordon Donaldson dari Harvard University mengajukan teori tentang informasi yang tidak simetris. Asymetric information adalah kondisi dimana suatu pihak memiliki informasi yang lebih banyak tentang perusahaan dibanding investor di pasar modal. Karena adanya asymetric information, Gordon Donadson menyimpulkan bahwa perusahaan lebih senang menggunakan dana dengan urutan : 1) laba ditahan dari depresiasi, 2) hutang dan 3) penjualan saham baru.

\subsection{Analisis Struktur Modal}

Untuk menganalisis struktur modal maka dapat digunakan rasio solvabilitas, antara lain:

a. Debt to Assets Ratio (DAR)

Rasio ini digunakan untuk mengukur seberapa besar jumlah aktiva perusahaan dibiayai dengan utang. Semakin tinggi rasio ini berarti semakin besar jumlah modal pinjaman yang digunakan untuk investasi pada aktiva guna menghasilkan keuntungan bagi perusahaan.

Debt to Total Asset Ratio $=\frac{\text { Hutang }}{\text { Total Aktiva }}$

b. $\quad$ Debt to Equity Ratio (DER)

Debt to Equity Ratio digunakan untuk mengukur perimbangan antara kewajiban yang dimiliki perusahaan dengan modal sendiri. Rasio ini juga dapat berati sebagai kemampuan perusahaan dalam memenuhi kewajiban membayar utangnya dengan jaminan modal sendiri. Rumusan untuk mencari DER dapat digunakan perbandingan antara total utang dengan total ekuitas sebagai berikut (Kasmir, 2008:158).

Debt to Equity Ratio $=\frac{\text { Total Debt }}{\text { Total Equity }}$

\section{c. $\quad$ Long term Debt to Equity Ratio (LDER)}

Rasio ini menunjukkan hubungan antara jumlah pinjaman jangka panjang yang diberikan kreditur dengan jumlah modal sendiri yang diberikan oleh pemilik perusahaan. Rasio ini juga digunakan untuk mengukur seberapa besar perbandingan antara utang jangka panjang dengan modal sendiri atau seberapa besar utang jangka panjang dijamin oleh modal sendiri. Rumusan untuk mencari LDER adalah dengan menggunakan perbandingan antara utang jangka panjang dengan modal sendiri sebagai berikut (Kasmir, 2008:159).

$$
\text { LDER }=\frac{\text { Total Long Term Debt }}{\text { Total Equity }}
$$

\subsection{Faktor - Faktor yang Mempengaruhi Struktur Modal}

Empat faktor utama yang mempengaruhi keputusan struktur modal (Brigham \& Houston, 2006) :

a. Resiko bisnis, atau resiko inheren dengan operasi resiko jika perusahaan tidak mempergunakan hutang.

b. Posisi perpajakan perusahaan, salah satu utama menggunakan hutang adalah bunganya yang dapat menjadi pengurangan 
pajak, yang selanjutnya akan mengurangi biaya utang efektif.

c. Fleksibilitas keuangan, atau kemampuan untuk memperoleh modal dengan persyaratan wajar dalam kondisi yang buruk.

d. Konservatif atau keagresifan manajemen, beberapa manajer lebih agresif dari yang lainnya, sehingga beberapa perusahaan cenderung menggunakan utang sebagai usaha untuk mendorong keuntungan.

\subsection{Struktur Modal yang Optimal}

Struktur modal yang optimal adalah struktur modal yang memaksimalkan harga dari saham perusahaan, dan hal ini biasanya meminta rasio utang yang lebih rendah daripada rasio yang memaksimalkan EPS yang diharapkan (Brigham \& Houston,2006).

Beberapa cara penentuan struktur modal yang optimal :

a. Pendekatan Laba Operasional Bersih (NOI) Pendekatan ini untuk struktur modal adalah teori struktur modal dengan biaya modal rata-rata tertimbang dan nilai total perusahaan tetap konstan ketika leverage keuangan berubah (Horne \& Wachowicz,2006).

b. Pendekatan Tradisional

Struktur modal yang meminimalkan biaya modal perusahaan dan karenanya memaksimalkan nilai perusahaan. Pendekatan ini menyarankan bahwa perusahaan awalnya dapat menurunkan biaya modal dan meningkatkan nilai totalnya melalui kenaikan leverage.

Cara lain lain dalam menentukan struktur modal optimal menurut Brigham \& Davis,2006 yang dikutip oleh lukas (1999) adalah ;

1. Menghitung biaya ekuitas pada berbagai tingkat penggunaan utang.

2. Menghitung nilai ekuitas pada berbagai tingkat penggunaan utang.
3. Menghitung total nilai perusahaan pada berbagai tingkat penggunaan utang.

4. Struktur modal optimum akhirnya dapat memaksimumkan nilai perusahaan.

\section{Biaya Agensi (Agency Cost)}

Biaya yang berhubungan dengan manajemen pengawasan untuk memastikan bahwa pihak manajemen berperilaku konsisten dengan kesepakatan kontraktual perusahaan dengan para kreditur serta pemegang saham. Pihak manajemen dapat dianggap sebagai agen dari para pemilik perusahaan yaitu para pemegang saham. Para pemegang saham berharap agar agen akan bertindak demi kepentingan para pemegang saham, akan mendelegasikan otoritas pengambilan keputusan ke pihak manajemen. Agar pihak manajemen dapat membuat keputusan yang optimal atas nama para pemegang saham, merupakan hal yang penting agar pihak manajemen tidak hanya mendapat intensif yang tepat seperti gaji, bonus opsi saham dan kompensasi, tetapi mereka akan di awasi juga.

Pengawasan yang dilakukan melalaui berbagai metode seperti pengikatan agen,audit laporan keuangan, dan secara eksplisit membatasi keputusaan pihak manajemen. Para kreditor mengawasi perilaku pihak manajemen dan pemegang saham dengan membebankan perjanjian jaminan dalam kesepakatan pinjaman pihak peminjam dan pemberi jaminan. Aktivitas pengawasan yang dimaksudkan tentunya melibatkan biaya.

Menurut Jensen dan Meckling (1976) agency cost dapat berupa :

1. Pengeluaran untuk memantau tindakan manajer (the monitoring expenditure by the principal ).

\section{The bonding Cost}

Biaya yang dikeluarkan oleh principal untuk mengendalikan terhadap agent, sehingga kemungkinan timbulnya perilaku yang tidak dikendaki semakin kecil. 


\section{Residual Lost}

Pengorbanan

karena

hilangnya/berkurangnya kesempatan untuk memperoleh laba karena dibatasinya kewenangan atau adanya perbedaan keputusan antara principal dan agent.

Agency cost yang diproksikan melalui insider ownership, institutional owership, collateralizable assets, debt to total assets, dan firm size (Arifanto, 2011).

Teori keagenan juga menyatakan bahwa konflik kepentingan antara manajemen dengan pemegang saham dapat diminimalisasi dengan suatu mekanisme pengawasan yang dapat mensejajarkan kepentingan-kepentingan yang terkait. Namun dengan munculnya mekanisme pengawasan tersebut akan memunculkan biaya yang disebut dengan agency cost (Wahidahwati, 2002).

Biaya keagenan (agency cost) tersebut dapat dikurangi dengan beberapa alternatif, yang antara lain: pertama, dengan meningkatkan kepemilikan saham perusahaan oleh manajemen. Kedua, dengan meningkatkan dividend payout ratio. Ketiga, meningkatkan pendanaan dengan hutang. Keempat, investor institusi sebagai monitoring agents (Wahidahwati, 2002).

\section{Dividen}

\subsection{Pengertian Dividen}

Menurut Ang (1997:68) yang dikutip oleh Arifanto (2011) dividen merupakan pendapatan bersih setelah pajak dikurangi dengan laba ditahan (retained earnings) yang ditahan sebagai cadangan perusahaan, maka dapat disimpulkan bahwa dividen adalah keuntungan yang dibagikan kepada para pemegang saham sehubung atas keuntungan yang diperoleh perusahaan.

\subsection{Kebijakan Dividen}

kebijakan dividen adalah praktik yang dilakukan oleh manajemen dalam membuat keputusan pembayaran dividen, yang mencakup besaran rupiahnya, pola distribusi kas kepada pemegang saham (Gumanti,2013:7)

Kebijakan dividen adalah kebijakan yang berhubungan dengan pembayaran dividen oleh pihak perusahaan, berupa penentuan besarnya dividen yang akan dibagikan dan besarnya saldo laba yang ditahan untuk kepentingan perusahaan (Sutrisno, 2001). Rasio pembayaran deviden (DPR) adalah deviden tunai tahunan yang dibagi dengan laba tahunan atau deviden per lembar saham di bagi laba perlembar saham (Fahmi, 2012:139). Rasio tersebut menunjukkan presentase laba perusahaan yang di bayarkan kepada pemegang saham secara tunai (Darmadji dan Fakhrudin,2001). Aspek utama dari kebijakan deviden perusahaan adalah menentukan alokasi laba yang tepat antara pembayaran deviden dengan penambahan laba ditahan perusahaan.

\subsection{Teori Kebijakan dividen}

Baker et al. (2007) menyimpulkan bahwa ada tujuh teori tentang dividen yang di kutip oleh Gumanti (2013) yaitu :

1. Teori burung di tangan (bird in the hand theory)

Menyatakan bahwa investor lebih menyukai dividen tunai daripada dijanjikan adanya imbal hasil dari investasi (capital gain) di masa yang akan datang. (Gordon, 1959; 1963; Walter, 1963, Litner, 1963).

2. Teori sinyal (Signaling theory)

Menyatakan bahwa divide akan mengurangi ketimpangan informasi (asymmetric of information) antara manajemen dan pemegang saham dengan menyiratkan informasi privat tentang prospek masa depan perusahaan. 
(Bhanttaracharya, 1979; John dan William, 1985).

3. Teori prefensi pajak (tax preference)

Menyatakan bahwa investor atau pemegang saham lebih menyukai perusahaan yang membagi dividen sedikit karena jika dividen yang dibayar tinggi, maka beban pajak yang harus ditanggung oleh investor atau pemegang saham juga akann tinggi. (Elton dan Gruber, 1970; Miller dan Scholes, 1978).

4. Teori efek klien (clientele effect theory) Menyatakan bahwa adanya perbedaan dalam besaran dividen yang dibagikan akan membentuk klien yang berbeda-beda juga. (Jensen dan Meckling, 1976; Easterbrook, 1984).

5. Teori keagenan (agency theory)

Menyatakan bahwa dividen membantu mengurangi biaya keagenan terkait dengan pemisahan kepemilikan dan kendali atas perusahaan. (Jensen dan Meckling, 1976; Easterbrook, 1984).

6. Teori siklus hidup (life cycle theory)

Menyatakan bahwa dividen cenderung untuk mengikuti pola siklus hidup perusahaan dan dividen yang dibagikan mencerminkan analisis manajemen atas pentingnya ketidaksempurnaan pasar termasuk didalamnya aspek-aspek yang berkaitan dengan pemegang ekuita, biaya keagenan, ketimpangan informasi, biaya penerbitan sekuritas, dan biaya-biaya transaksi. (Fama dan French, 2001; DeAngelo dan DeAngelo, 2006).

7. Teori katering (catering theory)

Menyatakan bahwa manajer memberi investor apa yang sebenarnya diinginkan investor, yaitu dengan membayar dividen manakala investor berani memberi premi harga saham yang tinggi tetapi manajer tidak akan membagi dividen manakala investor lebih menyukai perusahaan yang tidak membayar dividen (Baker dan Wulger, 2004a,b).

\subsection{Ukuran-ukuran Kebijakan Dividen}

Menurut Gumanti (2013:22), Ukuran yang pertama disebut sebagai imbal hasil dividen (dividend yield)., yang mengkaitkan besaran dividen dengan harga saham perusahaan. Secara matematis, rumus dividend yield adalah :

$$
\text { Dividen Yield }=\frac{\text { Dividend per lembar saham }}{\text { Harga Per Lembar Saham }}
$$

Dividend yield menjadi penting untuk dipahami karena menyiratkan ukuran bahwa komponen dari return total disumbangkan oleh dividen. Artinya, dalam menghitung return total, investor harus memasukkan unsur besarnya dividen yang diterima selain selisih harga saham antara awal dan akhir.

Ukuran yang kedua adalah Rasio pembayaran dividen (Dividend Payout Ratio). Rasio pembayaran dividen diukur dengan cara membagi besarnya dividen per lembar saham dengan laba bersih per lembar saham, yang secara matematis dapat dinyatakan dengan rumus berikut :

Dividend Payout Ratio $=\frac{\text { Dividend Per Share }}{\text { Earning Per Share }}$

Rasio pembayaran dividen digunakan dalam berbagai situasi. Misalnya, rasio tersebut digunakan dalam penilaian sebagai suatu cara untuk menduga besarnya dividen di tahun mendatang, karena kebanyakan analisis menggunakan pertumbuhan dalam laba daripada dividen. 


\subsection{Faktor-faktor yang Mempengaruhi Kebijakan Dividen}

Brigham dan Houston (2006) membagi empat kelompok besar faktor-faktor yang mempengaruhi kebijakan dividen perusahaan (lihat juga Weston dan Brigham, 1992) yaitu :

1. Kebijakan dividen dan kendala-kendala utama

a. Perjanjian kredit (debt covenant) atau pengakuan utang (debt indenture)

Sebagai pihak pemberi pinjaman kepada perusahaan, kreditor mempunyai kekuatan untuk memaksakan perjanjian uatang yang tidak merugikan dirinya. Kreditor dapat menggunakan perjanjian kredit yang mencegah manajemen untuk membagi dividen dalam jumlah besar. Dalam hal ini, pihak pemberi kredit berkepentingan untuk mendapatkan jaminan bahwa dana yang dipinjamkan akan kembali.

b. Ketidakcukupan keuntungan

Peraturan yang berlaku di negara-negara maju ada yang dikeluarkan dalam rangka untuk mengurangi upaya manajemen guna memaksakan diri untuk membagi dividen, sampai pada titik yang dianggap merugikan kreditor.

c. Ketersediaan kas

Dividen tunai hanya dapat dibayarkan jika jumlah kas yang tersedia diperusahaan mencukupi. Manajemen hanya memiliki alasan fundamental untuk tidak membayar jika memang keadaan arus kas diperusahaan tidak memungkinkan.

d. Denda pajak karena kecurangan pengakuan laba

Laba sebagai produk dari proses akuntansi, tidak tertutup dari kemungkinan adanya upaya membuat besaran laba sesuai dengan kehendak manajemen. Manajemen perusahaan sebagai wakil dari pemilik perusahaan, dapat menggunakan perusahaan untuk menghindari pajak pribadi.

2. Kebijakan dividen dan peluang investasi

a. Posisi dari peluang pertumbuhan investasi

Jika ada kecenderungan bahwa peluang investasi terbuka, maka manajemen akan mengurangi besaran dividen yang berarti ada peningkatan porsi laba ditahan (retention ratio), hal-hal lain dianggap konstan, rasio kecukupan utang perusahaan sudah tidak aman atau kurang menarik.

b. Potensi mempercepat atau menunda proyek

Jika peluang proyek yang ada mengharuskan perusahaan untuk segera merealisasinya, maka dividen akan berkurang. Sebaliknnya, jika masih memungkinkan untuk menunda proyek yang ada, manajemen memiliki kesempatan untuk membagi dividen sesuai dengan target sebelumnya.

3. Kebijakan dividen dan sumber - sumber pendanaan

a. Biaya atas penjualan saham baru

Kebutuhan untuk mendanai proyek baru yang menguntungkan dapat dipeuhi melalui sumber dana iternal, penerbitan surat utang, atau menerbitkan saham baru.

b. Kemampuan untuk mengganti ekuitas dengan utang

Posisi hutang di perusahaan juga dapat memengaruhi tinggi rendahnya dividen.

c. Keperluan pengendalian perusahaan Jika manajemen mengkhawatirkan aspek pengendalian, maka sangat besar kemungkinan bagi manajemen untuk menahan laba lebih tinggi atau mengurangi porsi dividen yang akan dibagikan. 


\section{Hipotesis}

Adapun hipotesis yang diajukan dalam penelitian ini adalah : " Diduga struktur modal, agency cost dan dividend payout ratio berpengaruh secara silmutan dan parsial terhadap kinerja perusahaan yang terdaftar di Bursa Efek Indonesia”.

\section{Kerangka Pemikiran}

Keterkaitan struktur modal, agency cost dan devident payout ratio terhadap kinerja perusahaan berdasarkan tujuan penelitian, tinjauan pustaka, dan hasil penelitian sebelumnya serta permasalahan yang telah dikemukan maka sebagai dasar merumuskan hipostesis, berikut disajikan kerangka pemikiran yang dituangkan dalam model penelitian.

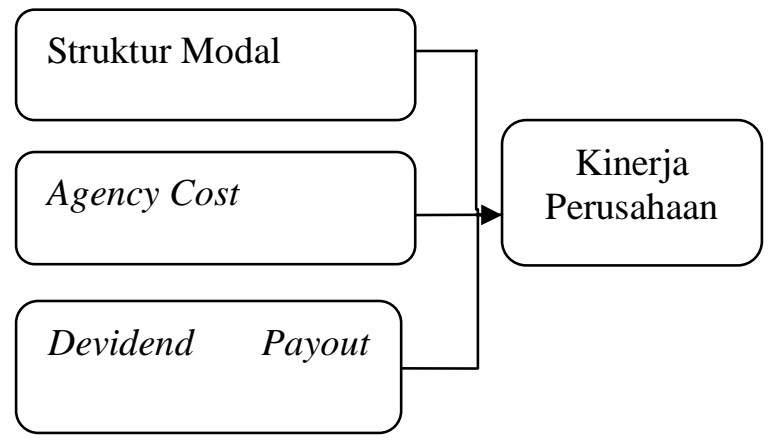

Gambar : Model Penelitian

\section{METODOLOGI PENELITIAN}

\section{A. Lokasi/Objek Penelitian}

Objek dalam penelitian ini dilakukan pada perusahaan yang Go publik dan terdaftar di Bursa Efek Indonesia Tahun 2008-2012. Dengan pengambilan data melalui Pusat Informasi Pasar Modal Riau ( PIPM - RIAU ) yang beralamatkan di Jl. Jend. Sudirman No. 73 Pekanbaru dan website resmi yang dimiliki oleh Bursa Efek Indonesia, yakni www.idx.co.id.

\section{B. Operasional Variabel}

Berdasarkan masalah dan hipotesis yang diajukan, maka digunakan beberapa variabel seperti tampak dibawah ini :

\section{Variabel Dependen}

Kinerja Perusahaan (Y)

Kinerja perusahaan memperlihatkan kemampuan perusahaan untuk memberikan keuntungan dari aset, ekuitas, maupun hutang. Kinerja perusahaan merupakan prestasi kerja perusahaan. Salah satu ukuran kinerja perusahaan adalah Return on Equity (ROE). ROE adalah ukuran profitabilitas perusahaan yang mengkur pengembalian untuk pemegang saham.

$$
\mathrm{ROE}=\frac{\mathrm{EAT}}{\text { Shareholders' Equity }}
$$

\section{Variabel Independen}

a. Struktur Modal $\left(\mathrm{X}_{1}\right)$

Struktur modal atau rasio leverage, yaitu jumlah hutang terhadap ekuitas.Rasio yang digunakan untuk mengetahui setiap rupiah modal sendiri yang dijadikan untuk jaminan hutang.

\section{Total Liabilities}

$$
\mathrm{DER}=\frac{\text { Total Shareholder's Equity }}{\text { ' Equ }}
$$

b. Agency cost $\left(\mathrm{X}_{2}\right)$

Menurut Lin (2006) dan Wright et.al menemukan bahwa berpengaruh terhadap kinerja. Variabel yang digunakan dalam penelitian ini adalah institusional ownership yaitu jumlah kepemilikan saham yang berbentuk institusi dari luar perusahaaan. Salah satu ukuran variabel ini adalah :

Saham yang dimiliki Institusi Institutional $=$ Ownership

Total Saham Beredar 


\section{c. Dividend Payout Ratio}

Rasio laba yang dibayarkan perusahaan sebagai dividen kepada investor pada periode waktu tertentu. Menurut Weston dan Brigham (1997), dividend payout ratio dapat dicari dengan menggunakan rumus :

$$
\mathrm{DPR}=\frac{\text { Dividend Per Share }}{\text { Earning Per Share }}
$$

\section{Populasi dan Sampel}

Populasi dalam penelitian ini adalah Perusahaan yang terdaftar di Bursa Efek Indonesia. Metode penentuan sampel menggunakan purposive sampling yaitu metode penentuan sampel yang tidak acak dan secara sengaja atau sesuai dengan pertimbangan tertentu (Sugiono, 2007). Kriteria - kriteria yang ditetapkan peneliti dalam pengambilan sampel adalah :

Perusahaan - perusahaan yang mempublikasikan laporan tahunan (Annual Report) secara berturut - turut dari tahun 2008 - 2012danselalu membagikan dividen secara berturut-turut selama periode pengamatan yaitu periode 2008-2012, serta memiliki data mengenai kepemilikan Institusional pada tahun 2008 - 2012.

Berdasarkan pertimbangan diatas, diperoleh 10 perusahaan yang diteliti selama periode 2008-2012 hal ini disebabkan karena kondisi pembayaran dividen setiap perusahaan berbeda-beda dan tidak semua perusahaan mengeluarkan dividen secara berturut setiap tahunnya, dengan demikian total sampel adalah 50 sampel.

\section{Analisis Data}

Analisis data yang dilakukan dengan analisis regresi berganda. Pengolahan data akan dilakukan dengan menggunakan bantuan program aplikasi SPSS 18,0.
Persamaan regresi linier berganda sebagai berikut :

$$
\mathbf{Y}=\alpha+\mathbf{b}_{1} \mathbf{X}_{1}+\mathbf{b}_{2} \mathbf{X}_{2}+\mathbf{b}_{3} \mathbf{X}_{3}+\mathbf{C}
$$

Dimana :

$\mathrm{Y}:$ Kinerja perusahaan

$\mathrm{X}_{1}$ : Struktur Modal

$\mathrm{X}_{2}$ : Agency Cost

$\mathrm{X}_{3}$ : Devident Payout Ratio

$\alpha$ : Nilai Konstanta

b1-b2-b3 : Koefisien Regresi X1, X2, X3

$\mathrm{C} \quad$ : Epsilon (variabel penganggu)

\section{HASIL PENELITIAN DAN PEMBAHASAN}

Pengaruh Debt to Equitu Ratio, Institutional Ownership, dan Dividend Payout Ratio Terhadap Return on Equity

Berdasarkan hasil analisis dapat diperoleh persamaan regresi berganda sebagai berikut :

$\mathrm{Y}=26,140+0,392 \mathrm{X}_{1}-0,188 \mathrm{X}_{2}-0,108 \mathrm{X}_{3}+\mathrm{e}$

Hasil korelasi secara parsial menunjukkan bahwa antara return on equity dan debt to equity sebesar 0,964. Sedangkan korelasi parsial antara return on equity dan institutional ownership sebesar -0,331 dan koefisien korelasi antara return on equity dan dividend payout ratio sebesar -,171 menunjukkan bahwa tidak ada hubungan antara return on equity dan dividend payout ratio.

Adapun adjusted R Square sebesar 0,927 atau $92,70 \%$. Koefisien ini menunjukkan bahwa 92,70\% perubahan yang terjadi pada Return on Equity dapat dijelaskan oleh variasi dari tiga bebas yaitu variabel DER, INSH, dan DPR, sedangkan sisanya $7,30 \%$ dijelaskan oleh variabel lain yang tidak diteliti.

\section{Pengaruh Debt to Equity ratio terhadap Return on Equity}


Berdasarkan hasil analisis regresi berganda secara parsial debt to equity ratio berpengaruh positif dan signifikan terhadap kinerja perusahaan. Hal ini sesuai dengan hipotesa awal yang menyatakan bahwa debt to equity ratio berpengaruh positif terhadap kinerja perusahaan. Hutang akan menambah modal bagi perusahaan dalam menjalankan operasional perusahaan dalam meningkatkan produktifitas dan laba. Penggunaan leverage yang bijaksana akan meningkatkan kinerja, hal ini akan meningkatkan imbal hasil kepada pemegang saham. Hasil penelitian sejalan dengan penelitian Khaira Amalia Fachrudin (2011) yang menyatakan bahwa struktur modal berpengaruh signifikan terhadap kinerja perusahaan. Hal ini mengindikasi bahwa hutang mampu meningkatkan kinerja perusahaan.

\section{Pengaruh Intitutional Ownership Terhadap Return on Equity}

Institutional Ownership berpengaruh signifikan terhadap kinerja perusahaan melalui analisis regresi secara parsial.Hal ini menunjukkan bahwa agensy cost berpengaruh negatif dan signifikan, ini sesuai dengan hipotesa awal yang menyatakan bahwa agency cost berpengaruh negatif terhadap kinerja perusahaan. Sejalan dengan temuan Lin (2006) yang menemukan bahwa agensy cost berpengaruh negatif dan siginifikan terhadap ROE artinya bila agency cost dibiarkan membengkak maka hal tersebut dapat mengurangi pencapaian keuntungan kompetitif yang berdampak negatif tehadap kinerja perusahaan.

\section{Pengaruh Dividend Payout Ratio} Terhadap Return on Equity

Berdasarkan dari hasil analisis regresi berganda secara parsial menunjukkan bahwa dividend payout ratio tidak berpengaruh terhadap kinerja perusahaan. Hal ini tidak sesuai dengan hipotesa awal yang menyatakan bahwa dividend payout ratio berpengaruh positif terhadap kinerja perusahaan. Karena pada penelitian ini terdapat kepemiikan institusi, yang mana penanaman modal cenderung besar dari pihak institusi, selain itu pihak institusi mengingikan pengembalian laba terhadap sahamnya lebih besar. Karena pihak institusi akan mempertimbangkan penanaman modal jika suatu investai tersebut tidak menguntungkan. Sehingga perusahaan akan lebih dominan memperhatikan pengembalian terhadap kepemilikan institusi.

\section{DAFTAR PUSTAKA}

Antari, Dewa Ayu Ratna dan Dana,I Made. 2010. Pengaruh Struktur Modal ,kepemilikan manajerial, dan Kinerja Keuangan terhadap Nilai Perusahaan. Falkutas Ekonomi, Universitas Udayana. Bali.

Ambarwati, Sri Dwi Ari. 2010. Manajemen Keuangan Lanjut. Yogyakarta. Graha Ilmu.

Atmaja, Lukas Setia. 2008. Teori \& Praktik Manajemen Keuangan. Yogyakarta. Andi.

Astuti, Dewi. 2004. Manajemen Keuangan Perusahaan. Jakarta. Ghalia Indonesia.

Brigham \& Houston. 2006. Dasar - Dasar Manajemen Keuangan. Jakarta. Salemba Empat.

Fachrudin, Khaira Amalia. 2011. Analisis Struktur Modal, Ukuran Perusahaan, dan Agency Cost Terhadap Kinerja Perusahaan. Falkutas Ekonomi USU. Medan.

Fitri, Hendri. Pengaruh EPS, PER dan DER Terhadap Return Saham Pada Perusahaan Manufaktur yang Terdaftar di BEI. Skripsi

Furi, Ratna dan Saifudin. 2012. Faktor Faktor yang Mempengaruhi Struktur 
Modal. Jurnal Akuntansi, Vol 1 (2); $\mathrm{h}: 49-62$.

Fahmi, Irham. 2012. Analisis Laporan Keuangan. Bandung. AlfaBeta.

Gumanti, Tatang Ary. 2013. Kebijakan Dividen: Teori, Empiris, dan Implikasi.Yogyakarta. UPP STIM YKPN.

Manurung, Adler Haymans. 2012. Teori Keuangan Perusahaan. Jakarta. Adler Manurung Press.

Sari, Nuzul Aulia, 2012. Pengaruh Komisaris Independen, Komite Audit, Kepemilikan Institusi, Reputasi Auditor, dan Kepemilikan Saham Oleh Publik Terhadap Kualitas Laba Perusahaan Real Estate dan Property yang Terdaftar Di BEI. Skripsi

Sunyoto, Dadang. 2011. Praktik SPSS Untuk Kasus. Yogyakarta. Nuha Medika.

Sudana, I Made. 2011. Manajemen Keuangan: Teori dan Praktik. Jakarta. Salemba Empat.

Supranto, J. 2009. Statistik: Teori dan Aplikasi. Jakarta.Erlangga.

Van Horne, J.C \& Wachowicz, J.M. 1998. Prinsip - prinsip Manajemen Keuangan. Jakarta. Salemba Empat.

http://www.idx.co.id (diakses tanggal 16 mei 2013, jam 20:13 wib)

http://www.jasaskripsitesis.com/2009/04/peng aruh-agency-costs-terhadapdividend.html (diakses tanggal 18 mei 2013, jam 19:45 wib)

http://www.sarjanaku.com/2012/06/teorikeagenan-agency-theory.html (diakses tanggal 23 mei 2013, 21:00 wib)

http://jurnal-sdm.blogspot.com/2009/07/teoristruktur-modal-pengertian-dan.html (diakses tanggal 23 mei 2013, 21:35 wib)

http://supina.blog.esaunggul.ac.id/2012/04/10/ rasio-untuk-mengukur-kinerja- perusahaan /(diakses tanggal 23 mei 2013, 21:44 wib)

http://respository.upi.edu/2520/4/t-mmb1103441-chapter/pdf. (diunggah $7 \mathrm{feb}$ Jruari 2014, 23.41 WIB) 